\title{
Purification of laccase I from Armillaria mellea
}

\author{
Ata Ur Rehman† and Christopher F. Thurston* \\ Microbiology Group, Division of Biosphere Sciences, King's College London, Campden Hill Road, London W8 7AH, UK
}

(Received 18 December 1991; accepted 28 February 1992)

\begin{abstract}
Laccase activity accumulated during rhizomorph development in malt extract cultures of Armillaria mellea. The activity was readily separated into two bands by PAGE under non-denaturing conditions. The less rapidly migrating activity (on PAGE) was purified by ammonium sulphate precipitation, anion-exchange chromatography and gel filtration. The purified enzyme (laccase I) showed a main polypeptide of $M_{\mathrm{r}} \mathbf{5 9 0 0 0}$. Activity of the purified enzyme was greatest with 2,6-dimethoxyphenol (DMOP) as substrate. Syringaldazine, p-phenylenediamine and other typical laccase substrates were readily oxidized. No oxidation of tyrosine was detected. The $K_{m}$ for DMOP was $0.178 \mathrm{mM}$ and for $p$-phenylenediamine was $1.69 \mathrm{mM}$. The pH optimum for $p$-phenylenediamine oxidation was 3.5. Electrophoretically purified main polypeptide of laccase I was used to raise a specific antibody. Immunoblot analysis showed that whilst the antibody bound strongly to laccase I, no binding to laccase II was detectable. Antibody raised against pure laccase from Agaricus bisporus reacted with laccase I from Armillaria mellea but not with laccase II. The isolectric pH was $4 \cdot 1$ for laccase I and 3.3 for laccase II.
\end{abstract}

\section{Introduction}

Secretion of extracellular laccase (polyphenoloxidase, EC 1.10.3.2) is a common property amongst basidiomycete fungi. In organisms such as Sporotrichum pulverulentum and Phlebia radiata a function related to lignin degradation has been proposed (Ander \& Eriksson, 1976; Kantelinen et al., 1989). A similar function may apply to the constitutively produced laccase of Agaricus bisporus (Wood, 1985). In contrast, other basiodiomycetes such as Lentinus edodes and Schizophyllum commune secrete laccase in association with fruit body development (Leatham \& Stahmann, 1981; De Vries et al., 1986). Armillaria mellea secretes laccase activity in association with the differentiation of vegetative mycelium to form rhizomorphs (Worrell et al., 1986). Although not all Armillaria spp. produce rhizomorphs, root infection by these strand-like structures formed of numerous hyphae is a principal means of vegetative spread of the fungus in forest stands (Wargo, 1990). In this paper some properties of laccase secreted

- Author for correspondence. Tel. 071333 4276; fax 0719375396.

† Present address: Plant Tissue Culture Laboratory, National Agricultural Research Centre, PONIH, Islamabad, Pakistan.

Abbreviation: DMOP, 2,6-dimethoxyphenol. by $A$. mellea during rhizomorph formation in liquid culture are reported.

\section{Methods}

Organism. Armillaria mellea 8R was obtained from J. Rishbeth (University of Cambridge, UK). It was originally isolated from dead Rosa spp. in January 1983 at Cambridge. The culture was maintained on $2 \%(w / v)$ malt extract $1 \%(w / v)$ agar slopes grown at $25^{\circ} \mathrm{C}$ and stored at $4{ }^{\circ} \mathrm{C}$.

Growth medium. Experimental cultures were grown in $3 \%(\mathrm{v} / \mathrm{v})$ malt extract syrup (Boots plc, England) adjusted to pH 5.0, except where stated otherwise, and autoclaved at $118^{\circ} \mathrm{C}$ for $10 \mathrm{~min}$. It was determined experimentally that $3 \%(\mathrm{v} / \mathrm{v})$ malt extract syrup was equivalent to $2 \cdot 2 \%(\mathrm{w} / \mathrm{v})$ dry matter of malt extract.

Culture conditions. For purification of laccase enzymes $100 \mathrm{ml}$ medium in 1 litre Roux bottles was inoculated with six $6 \mathrm{~mm}$ plugs cut from the growing margin of an $\boldsymbol{A}$. mellea colony growing on malt extract agar. Generally $20-24$ bottles were used. The bottles were sealed with vaccine stoppers or rubber bungs and incubated laid flat at $25^{\circ} \mathrm{C}$ in the dark. Incubation was static but the bottle contents were mixed gently once per day. Where other bottles and medium volumes were used, details are given in figure legends. Culture filtrate was recovered by filtration first through cheese-cloth and subsequently through sintered glass filters (porosity no. 2).

Laccase assay. Laccase activity was determined quantitatively by polarographic measurement of oxygen consumption (Wood, 1980). 
Assay mixtures contained (in $1 \mathrm{ml}$ ): $27 \mu \mathrm{mol}$ citric acid/disodium hydrogen phosphate buffer, $\mathrm{pH} 4 \cdot 0,15 \mu \mathrm{mol} p$-phenylenediamine and culture filtrate or enzyme fraction added as up to $30 \%$ of the total volume. The reaction was initiated by addition of the $p$-phenylenediamine and oxygen consumption was followed at $25^{\circ} \mathrm{C}$ in a stirred reaction vessel with a Clark-type oxygen electrode in its base (Rank Brothers, Cambridge). Enzyme activity was expressed as $\mu \mathrm{mol}$ oxygen consumed $\min ^{-1}$.

The position of laccase activity on gels after non-denaturing electrophoresis or isoelectric focussing was revealed by incubation with 10 mM-guaiacol (Wood, 1980) or $0.05 \%$ syringaldazine, from which laccase gives an intensely purple-coloured product (Harkin et al., 1974).

Electrophoresis. SDS-PAGE was performed as described by Laemmli (1970). Non-denaturing electrophoresis was performed under the same conditions except that $\beta$-mercaptoethanol and SDS were omitted.

Isoelectric focussing (IEF). The Phast Gel system (Pharmacia) was used with gels that generated a gradient from $\mathrm{pH} 3$ to $\mathrm{pH} 9$.

Protein detection and quantification. After electrophoresis and IEF, protein on gels was stained with Coomassie brilliant blue or with silver using a Bio-Rad kit according to the manufacturer's instructions. Protein concentration was determined using the method of Hess et al. (1978) with bovine serum albumin as standard. During protein purification, protein concentration was monitored as $A_{280}$ after the first anion-exchange chromatography step.

Purification procedures. All steps were carried out at $0-4{ }^{\circ} \mathrm{C}$. Culture filtrate ( 2.21 litres) was concentrated fivefold in an Amicon 8400 cell using PM10 membranes $\left(M_{\mathrm{r}}\right.$ cut-off 10000). The concentrated filtrate was made $90 \%$ saturated in ammonium sulphate. The precipitate was recovered by centrifugation and resuspended in $300 \mathrm{ml} 60 \%$ saturated ammonium sulphate in $0.1 \mathrm{M}$-potassium phosphate, $\mathrm{pH} 7.0$. After stirring for $1 \mathrm{~h}$ the undissolved precipitate was recovered by centrifugation (retaining $98 \%$ of the laccase activity of the first precipitate) and dissolved in $440 \mathrm{ml} 0.01 \mathrm{M}$-potassium phosphate, $\mathrm{pH} 7.0$ (hereafter, buffer A). This solution was dialysed for $18 \mathrm{~h}$ against buffer A prior to loading onto a DEAE-Sephadex A-50 column (Pharmacia, $2.6 \times$ $40 \mathrm{~cm}$ ), previously equilibrated with buffer $A$. The column was washed with 5 vols buffer $A$ and eluted with a $600 \mathrm{ml}$ gradient of $0.2-0.6 \mathrm{M}$ $\mathrm{NaCl}$ in buffer $\mathrm{A}$. Fractions containing laccase activity were pooled and concentrated to $3.3 \mathrm{ml}$ by ultrafiltration over a PM10 membrane. The concentrated sample was applied to a Sephacryl S-300 Superfine column (Pharmacia, $2.6 \times 60 \mathrm{~cm}$ ) at a flow rate of $20 \mathrm{ml} \mathrm{h}^{-1}$ and eluted with buffer $A$ at $40 \mathrm{ml} \mathrm{h}^{-1}$. Active fractions from gel filtration were pooled and loaded onto a second DEAE-Sephadex A-50 column which was equilibrated, washed and eluted as above. Laccase I activity was eluted in two or three $6 \mathrm{ml}$ fractions which were pooled, dialysed against buffer $A$ and concentrated 5 to 10 -fold by untrafiltration prior to storage at $-70^{\circ} \mathrm{C}$ as $150 \mu \mathrm{l}$ aliquots. Laccase II activity was retained as the most active fractions from a less well-defined peak and treated similarly.

Anti-laccase I antibody. Laccase I purified as described above was subjected to SDS-PAGE. The main polypeptide band was eluted from the gel in the presence of $0.1 \%$ SDS. This preparation (Fig. 5) was used as an immunogen. A rabbit was initially injected subcutaneously with $200 \mu \mathrm{g}$ laccase protein in complete Freund's adjuvant. Subsequently $100 \mu \mathrm{g}$ laccase protein in incomplete Freund's adjuvant was injected at 2-3 week intervals for 12 weeks. Antibody titre was monitored by ELISA assays (data not shown). IgG was purified from antiserum as described by Krugger \& Hammond (1988).

Immunoblot analysis. The IgG fraction described above was used at 1 in 100 dilution. Anti-Agaricus bisporus laccase IgG fraction (prepared by C. R. Perry and C. F. Thurston) was used at 1 in 800 dilution. The method was as described previously (Pacy \& Thurston, 1987). Pure laccase from Agaricus bisporus was a gift from Dr D. A. Wood, Horticulture Research International, Littlehampton, UK.

\section{Results}

\section{Accumulation of laccase activity in the medium of A. mellea cultures}

Appearance of laccase activity in the medium of $\boldsymbol{A}$. mellea cultures correlates with synthesis of rhizomorphs (Worrell et al., 1986). In a series of preliminary experiments, it was established that higher levels of laccase activity were obtained in malt extract medium than in the defined medium employed by Worrell et al. (1986) and that shallow layers of liquid medium that allowed the relatively rapid development of aerial mycelium gave higher levels of laccase activity (and rhizomorph dry weight). Although the dry weight of rhizomorph tissue was marginally greater in medium adjusted initially to $\mathrm{pH} 7 \cdot 0$, more laccase activity was found in cultures with medium adjusted to pH 5.0 (Fig. 1).

Production of extracellular laccase was affected by the aeration of the cultures. When the culture bottles were sealed (rubber bungs or vaccine stoppers) after inoculation, the amount of laccase activity that accumulated was greater than when the bottles were closed with foam plugs (Fig. 2). Sealed flasks also resulted in the maintenance of high laccase activity for longer periods; with foam bungs the activity declined rapidly after reaching a maximum about 2 weeks after inoculation. Non-denaturing PAGE showed that two laccase activities were present in the medium (see Fig. $4 a$, track 1) and the relative amount of the two bands (stained for enzyme activity) was similar at all stages of culture on the basis of visual inspection.

\section{Purification of laccase enzyme protein}

Table 1 shows data for a typical purification. Culture medium was concentrated about fivefold by ultrafiltration prior to ammonium sulphate precipitation. The dialysed ammonium sulphate precipitate gave a dark brown solution. The majority of the pigmented material adsorbed to the DEAE-Sephadex column and could not be displaced by increasing the ionic strength (up to $1.0 \mathrm{M})$. Laccase activity was eluted as a single peak which was again concentrated by ultrafiltration. It should be noted that only $57 \%$ of the activity applied to the DEAESephadex column was recovered. This step of the purification was necessary, however, to remove pigmented polyphenolic material. Gel filtration gave a single peak of eluted laccase activity, removing about half the 

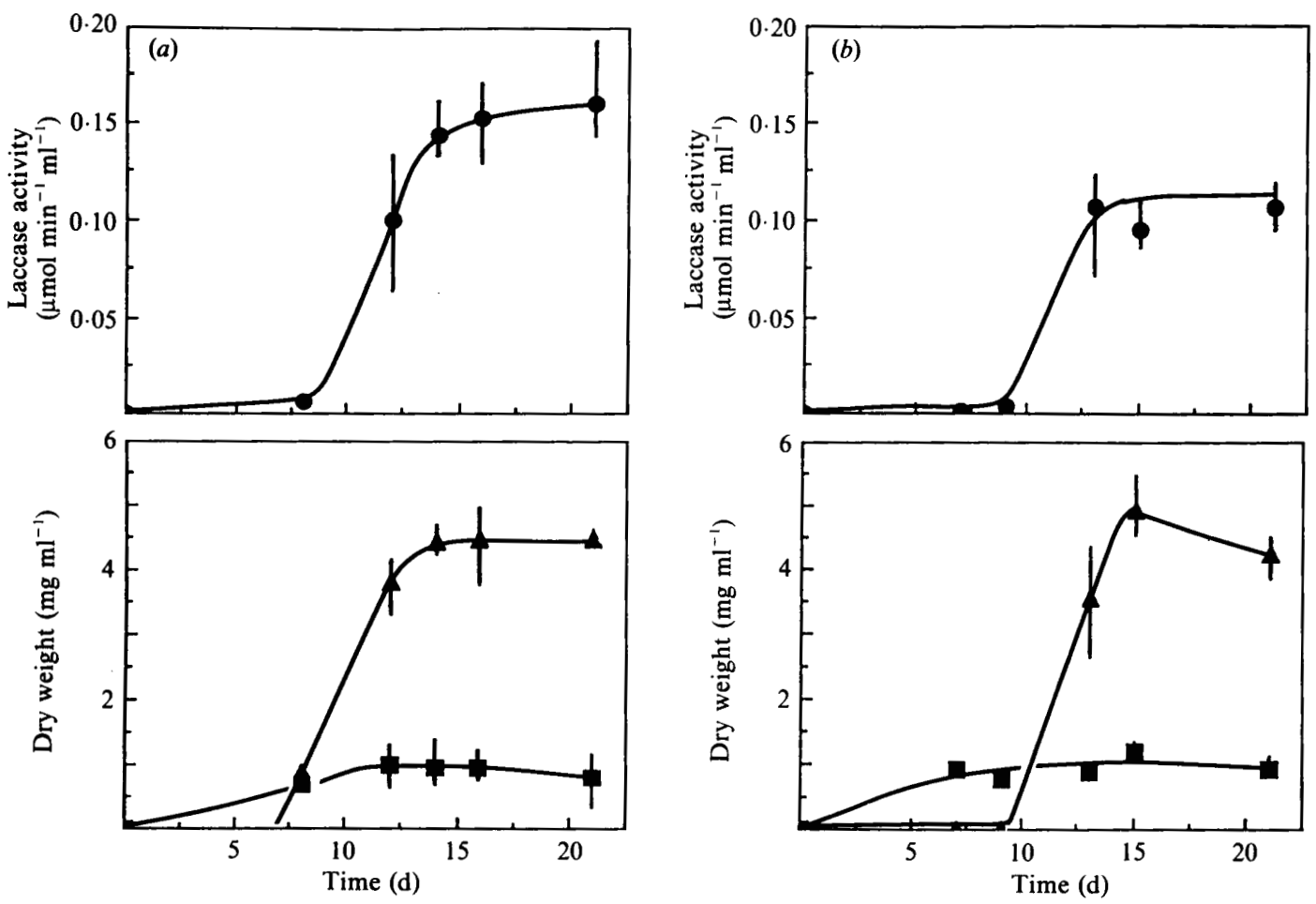

Fig. 1. Effect of culture medium pH on laccase synthesis and rhizomorph development. Cultures $(20 \mathrm{ml})$ in $100 \mathrm{ml}$ flat bottles were set up with malt extract medium adjusted to $\mathrm{pH} 5(a)$ or $\mathrm{pH} 7(b)$. Laccase activity (O) upper panels) was assayed (at pH 4) as described in Methods. The lower panels show undifferentiated mycelium $(\boldsymbol{D})$ and rhizomorph $(\boldsymbol{\Delta})$ dry weight. Mycelium and rhizomorph tissue were dissected apart prior to drying. All values are means of four determinations. Vertical lines show the range where this exceeds the size of the data symbols.

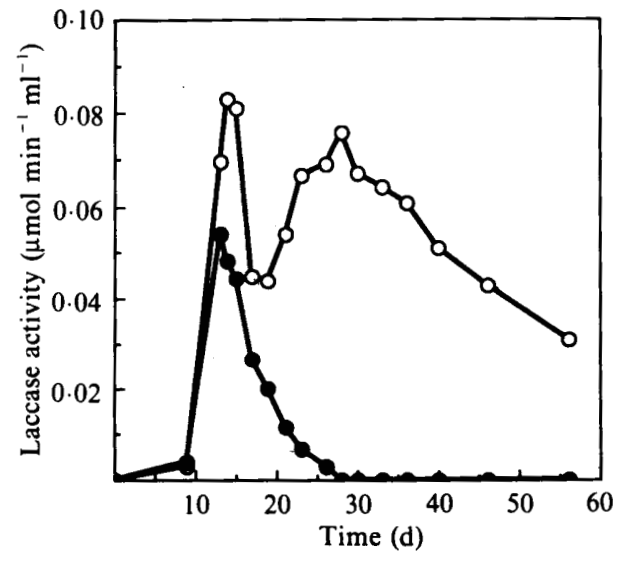

Fig. 2. Effect of aeration on laccase synthesis. Cultures $(100 \mathrm{ml})$ in 1 litre Roux bottles were incubated either sealed with vaccine stoppers $(O)$, or closed only with porous foam plugs (O), allowing exchange of atmosphere between the inside and outside of the bottles during incubation. The data are means of triplicate assays on samples withdrawn via a syringe needle, thus not requiring the sealed bottles to be opened.

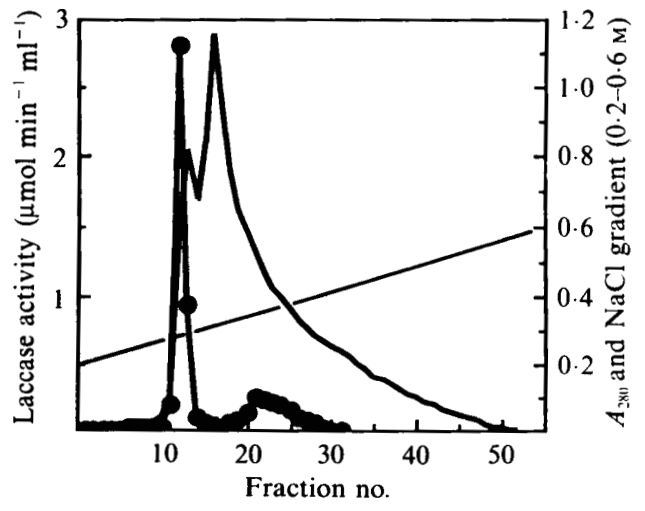

Fig. 3. Elution of laccase activity ( $)$ and protein from the second DEAE-Sephadex column step of laccase purification. Fraction volume was $6 \mathrm{ml}$. See Table 1 and Methods for further details.

contaminating protein present at this stage. Finally a second salt-gradient elution from a DEAE-Sephadex column gave two active fractions (Fig. 3). The first, eluting at $0.3 \mathrm{M}-\mathrm{NaCl}$, constituted nearly a third of the 
(a)

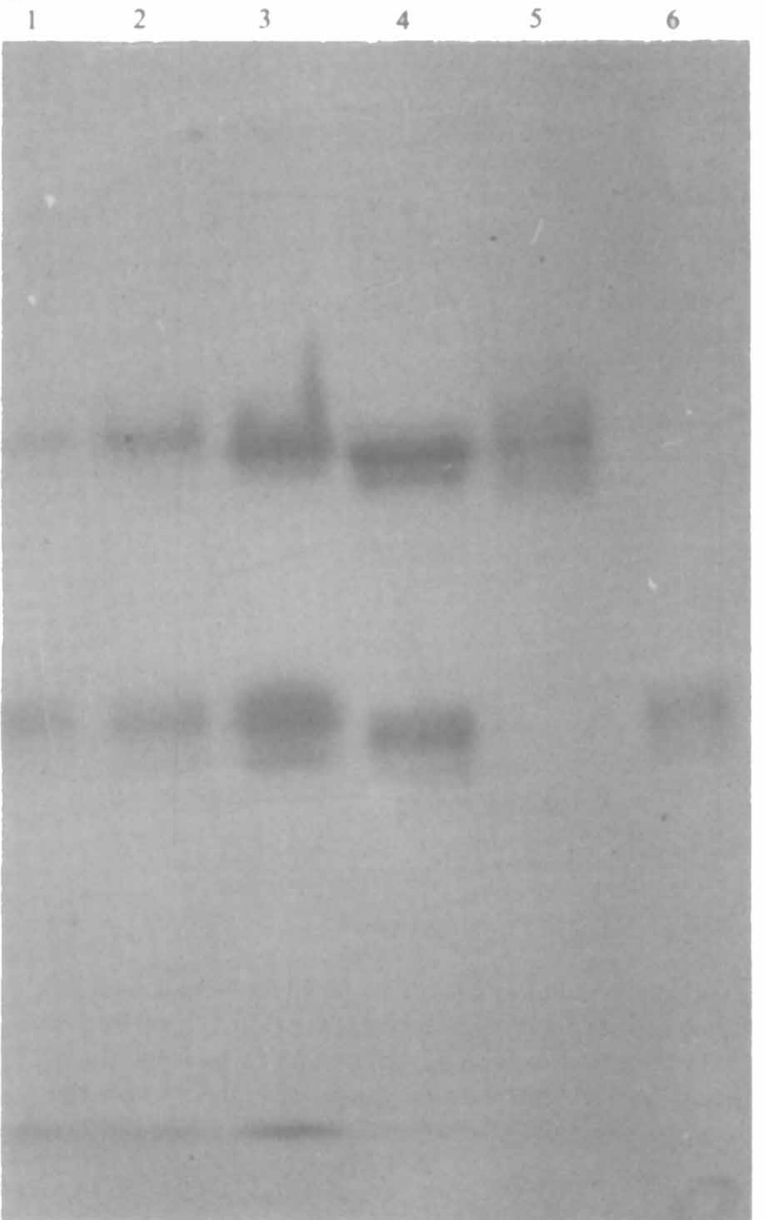

(b)

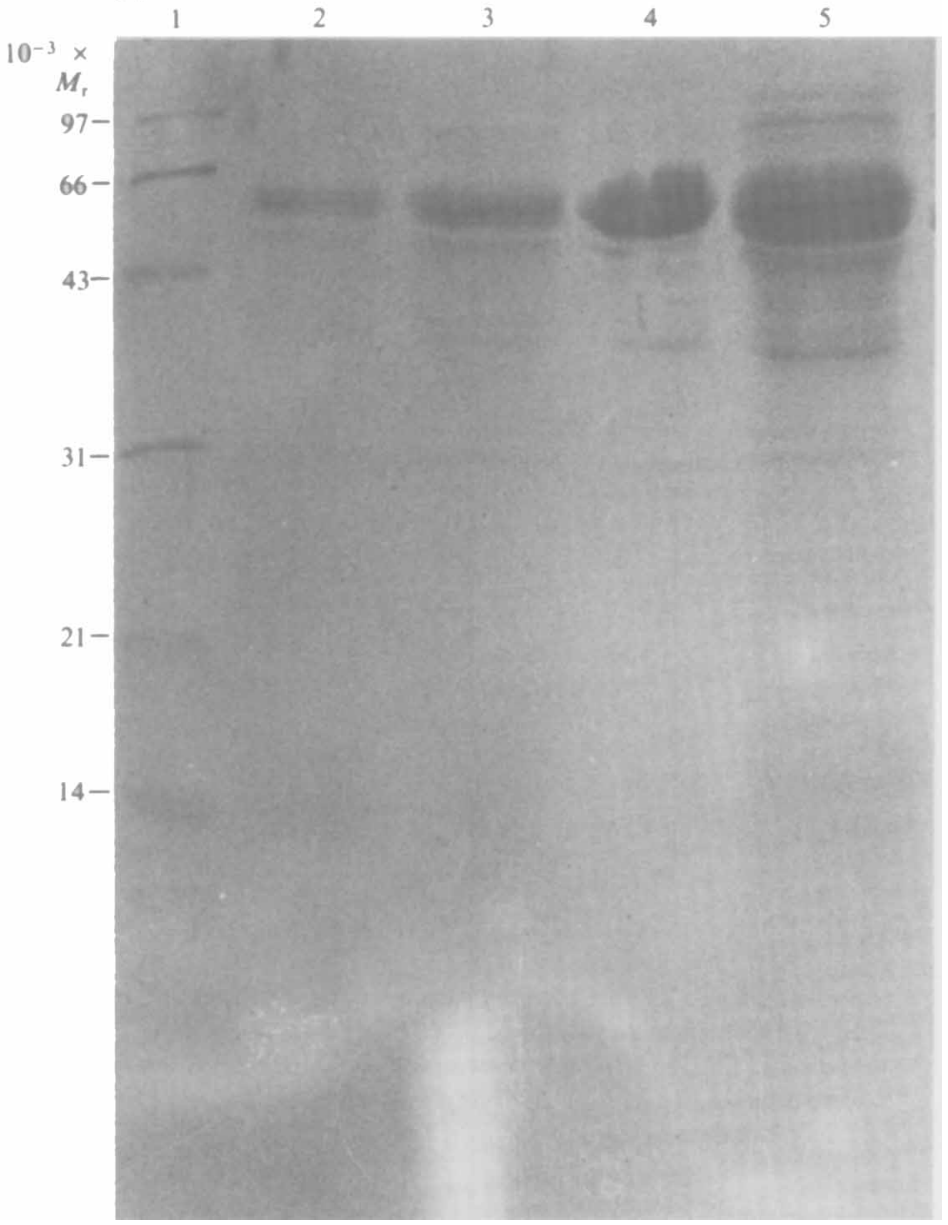

Fig. 4. (a) Separation of laccase I from laccase II. Non-denaturing $10 \%$ PAGE was followed by staining for laccase activity with

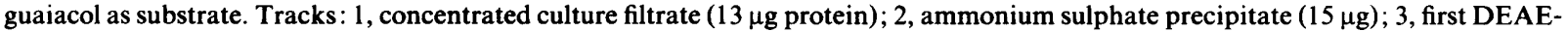
Sephadex column eluate $(15 \mu \mathrm{g}) ; 4$, Sephacryl gel filtration eluate $(8 \mu \mathrm{g}) ; 5$, first peak (laccase I) from the second DEAE-Sephadex column steps $(2 \mu \mathrm{g}) ; 6$, second peak (laccase II) from the second DEAE-Sephadex column $(2 \mu \mathrm{g})$. (b) SDS-PAGE (12\% gel) analysis of purified laccase I. Track $1, M_{\mathrm{r}}$ markers: phosphorylase $b$ (97000), bovine serum albumin (66000), ovalbumin (43000), carbonic anhydrase (31000), soybean trypsin inhibitor (21000) and hen egg lysozyme (14000). Tracks 2,3 and 5, purified laccase I (10, 20 and $80 \mu \mathrm{g}$ protein, respectively). Track 4, electro-eluted protein from a non-denaturing PAGE gel loaded with purified laccase I, from the region of the gel showing laccase activity. Protein stained with Coomassie brilliant blue.

Table 1. Purification of laccase from A. mellea culture filtrate

\begin{tabular}{|c|c|c|c|c|c|c|}
\hline Purification step & $\begin{array}{l}\text { Volume } \\
\text { (ml) }\end{array}$ & $\begin{array}{l}\text { Total } \\
\text { protein } \\
(\mathrm{mg})\end{array}$ & $\begin{array}{c}\text { Total } \\
\text { enzyme activity } \\
\left(\mu \mathrm{mol} \mathrm{min}^{-1}\right)\end{array}$ & $\begin{array}{l}\text { Specific activity } \\
{\left[\mu \mathrm{mol} \mathrm{min} \mathbf{m}^{-1}\right.} \\
\left.(\mathrm{mg} \text { protein })^{-1}\right]\end{array}$ & $\begin{array}{l}\text { Purification } \\
\text { (-fold) }\end{array}$ & $\begin{array}{c}\text { Yield } \\
(\%)\end{array}$ \\
\hline Culture filtrate & 2120 & 190 & 148 & 0.78 & 1 & 100 \\
\hline Concentrated filtrate & 440 & 118 & 140 & $1 \cdot 18$ & 1.51 & 94 \\
\hline Ammonium sulphate $(60 \%$ satd $)$ & 307 & 31 & 102 & $3 \cdot 31$ & $4 \cdot 25$ & 68 \\
\hline DEAE-Sephadex column I & $3 \cdot 3$ & $8 \cdot 25$ & $57 \cdot 2$ & 6.93 & 8.89 & 38 \\
\hline Sephacryl S-300 & 90 & $4 \cdot 50$ & $56 \cdot 7$ & $12 \cdot 6$ & $16 \cdot 1$ & 38 \\
\hline \multicolumn{7}{|l|}{ DEAE-Sephadex column II } \\
\hline First peak & 3.6 & 1.08 & $43 \cdot 6$ & $40 \cdot 4$ & $51 \cdot 7^{*}$ & $29 *$ \\
\hline Second peak & $1 \cdot 2$ & 0.36 & $12 \cdot 1$ & $33 \cdot 7$ & $43 \cdot 1^{*}$ & $8^{*}$ \\
\hline
\end{tabular}

* The calculation of these values does not correct for the presence of two separable activities. For instance, if the culture filtrate contained equal amounts of first- and second-peak activities, the true purification and yield values would be double those shown. 


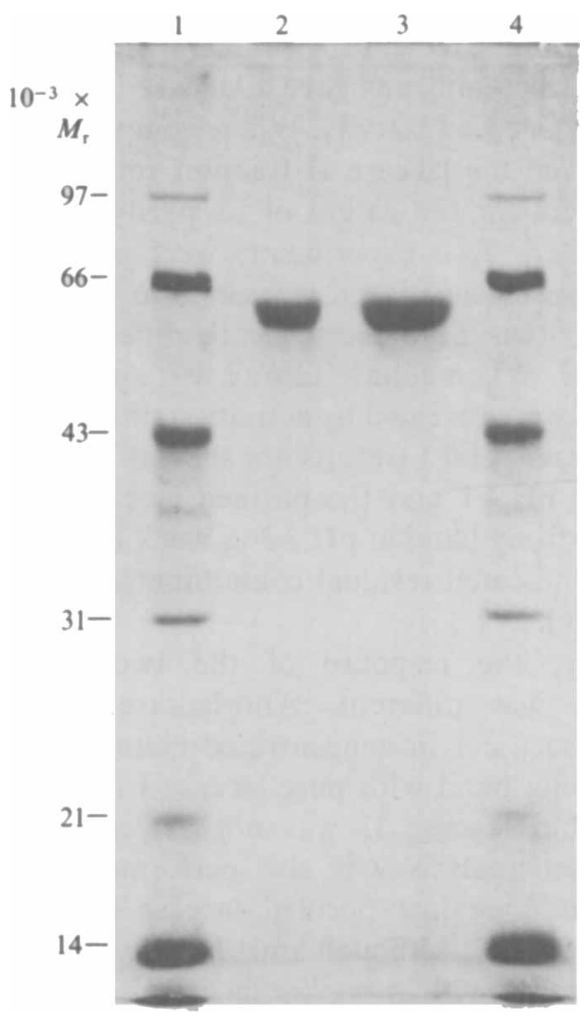

Fig. 5. Gel-purified laccase I main polypeptide. Purified laccase I was separated by SDS-PAGE $(10 \%$ gel) and the main band cut out and electro-eluted, after location by brief staining with Coomassie brilliant blue. Tracks 1 and 4, $M_{\mathrm{r}}$ markers as described in the legend to Fig. $4(b)$. Tracks 2 and 3,10 $\mu \mathrm{g}$ and $20 \mu \mathrm{g}$, respectively, of gel-purified laccase I main polypeptide. Proteins were silver stained.

original activity and is referred to subsequently as laccase I. The second peak, eluting at about $0.38 \mathrm{M}-\mathrm{NaCl}$, was always only a small fraction $(<10 \%)$ of the initial activity and is referred to as laccase II. The two activities present in culture filtrate were therefore separated (Fig. 4).

Laccase I gave a single predominant band on SDSPAGE with an apparent $M_{\mathrm{r}}$ of 59000 (Figs $4 b$ and 5). When purified laccase I was analysed by non-denaturing PAGE, the protein resolved as up to four bands close together. All bands that stained for protein also stained for laccase activity (Fig. 6). It is probable that most if not all of the minor protein bands seen in SDS-PAGE analysis of laccase I (Fig. $4 b$ ) are fragments of the fulllength polypeptide as they reacted with antibodies raised against the gel-purified full-length polypeptide.

\section{Properties of laccase I from A. mellea}

Purified laccase I showed optimum activity at $\mathrm{pH} 3.5$ and only about $10 \%$ of this activity at pH 6.5 (Fig. 7).

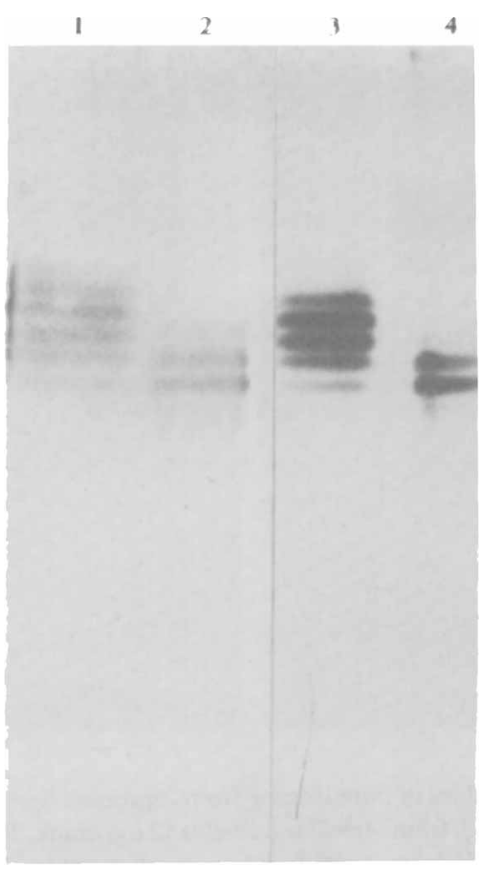

Fig. 6. Non-denaturing PAGE of purified laccase I. Tracks 1 and 2 show purified laccase I from two separate purification experiments, stained for laccase activity with guaiacol as substrate (both tracks loaded with approx. $20 \mu \mathrm{g}$ protein). Tracks 3 and 4 show samples from the same preparations stained for protein with Coomassie brilliant blue (both tracks loaded with approx. $80 \mu$ g protein).

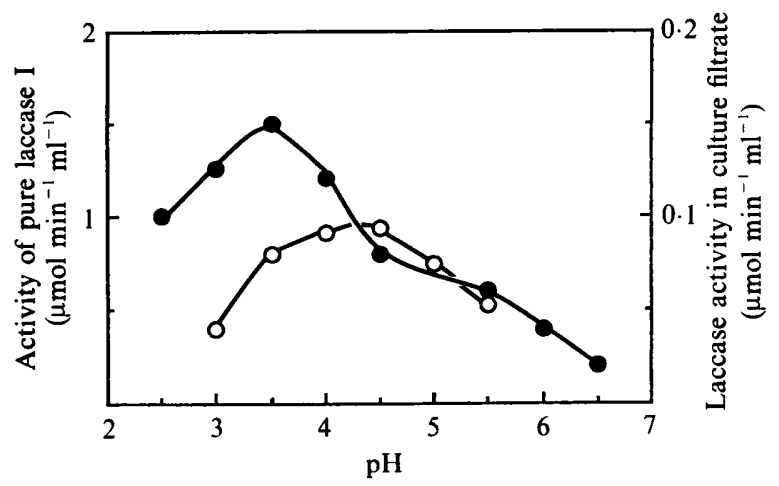

Fig. 7. Effect of assay pH on laccase activity. Laccase activity was assayed in phosphate/citrate buffers adjusted to $\mathrm{pH}$ values between 2.5 and $6 \cdot 5$, testing concentrated $A$. mellea culture filtrate $(O)$ and purified laccase I (O).

The broader $\mathrm{pH}$ optimum of laccase activity in unfractionated culture filtrate may indicate a higher $\mathrm{pH}$ optimum for laccase II. Laccase I was active against a range of typical laccase substrates (Table 2), with DMOP showing the greatest rate of oxidation. Tyrosine was not oxidized. The enzyme exhibited normal substrate 

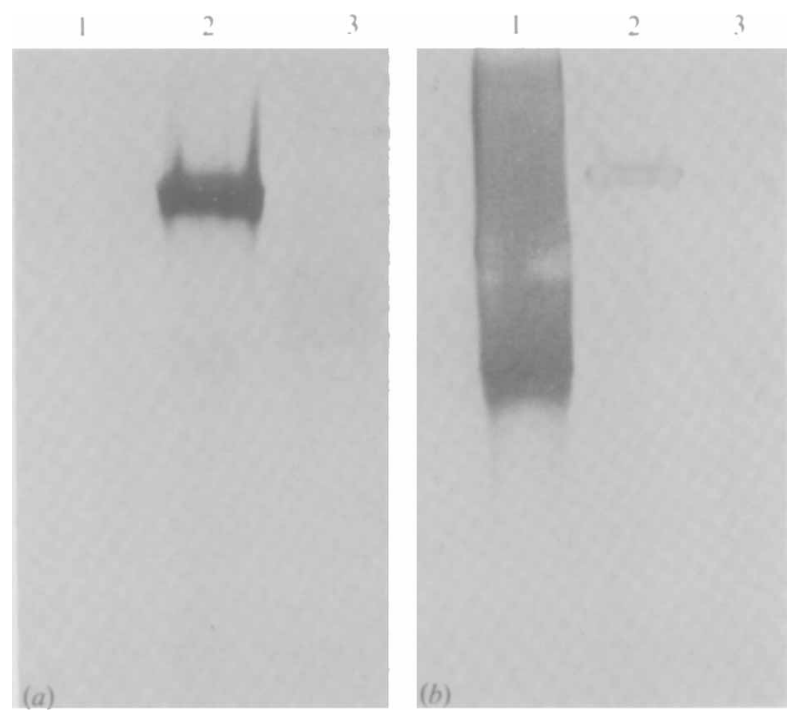

Fig. 8. Immunoblot of pure laccase from Agaricus bisporus $(8 \mu \mathrm{g}$, track 1), pure laccase I from Armillaria mellea ( $2 \mu \mathrm{g}$, track 2$)$ and partially purified laccase II from A. mellea $(4 \mu \mathrm{g}$, track 3$)$. After electrophoresis under non-denaturing conditions proteins were transferred to nitrocellulose paper and reacted with anti-A. mellea laccase I IgG $(a)$ or anti-Ag. bisporus laccase IgG (b).

Table 2. Substrate specificity of purified laccase I from A. mellea

Enzyme activity was measured as the rate of oxygen consumption. Data are mean values from quadruplicate assays.

\begin{tabular}{lc}
\hline \hline \multicolumn{1}{c}{ Substrate (all at $15 \mathrm{mM}$ ) } & Relative activity \\
\hline$p$-Phenylenediamine & $1 \cdot 0$ \\
Syringaldazine & $0 \cdot 82$ \\
Guaiacol & $0 \cdot 95$ \\
$N, N$-Dimethyl-1,4-phenylenediamine & $1 \cdot 19$ \\
Catechol & $1 \cdot 18$ \\
2,6-Dimethoxyphenol (DMOP) & $1 \cdot 59$ \\
Tyrosine & 0 \\
\hline \hline
\end{tabular}

saturation kinetics when tested with a range of concentrations of $p$-phenylenediamine and DMOP. The $K_{\mathrm{m}}$ for $p$-phenylenediamine was $1.69 \mathrm{mM}$ and for DMOP was $0.178 \mathrm{mM}$. Purified laccase I retained full activity during storage at $-70{ }^{\circ} \mathrm{C}$ for six months.

\section{Comparison of laccase I and laccase II from A. mellea}

The purification procedure described above yielded a fraction containing laccase II, but the amount of this material was insufficient for complete characterization. Not all purification runs gave a laccase II fraction that was free of laccase I activity. Where complete separation was achieved the laccase II fraction contained insuffcient protein for the extent of its purity to be clearly demonstrated. Two experiments were performed that clearly show laccase I and laccase II to be distinct.

First, the two enzymes had clearly different properties during IEF. When culture filtrate was analysed by IEF two bands were revealed by activity staining for laccase, at pH 3.3 and pH 4.1 (results not shown). Pure laccase I focused at $\mathrm{pH} 4 \cdot 1$ and the purified laccase II fraction showed a strong band at $\mathrm{pH} 3 \cdot 3$ (a weak band at $\mathrm{pH} 4 \cdot 1$ probably indicated residual contaminating laccase $\mathrm{I}$ in this sample).

Secondly, the response of the two enzymes to antibodies was different. Anti-laccase I antiserum detected laccase $I$ in concentrated culture filtrate and gave a strong band with pure laccase $I$ in immunoblot analysis, but laccase II was not detected (Fig. 8a). Immunoblot analysis was also performed using antibodies raised against purified laccase from Agaricus bisporus (Fig. 8b). Although anti-Ag. bisporus antibodies reacted weakly with $A$. mellea laccase I, no binding to laccase II was detected.

\section{Discussion}

The properties so far demonstrated for A. mellea laccase I (i.e. size, $\mathrm{pH}$ optimum, substrate specificity and $\mathrm{pI}$ ) are not untypical of extracellular fungal laccases. A polypeptide of $M_{\mathrm{r}}$ about 60000 has been verified by DNA sequencing for laccases from Neurospora crassa (German et al., 1988), Aspergillus nidulans (Aramayo \& Timberlake, 1990), Coriolus hirsutus (Kojima et al., 1990) and Phlebia radiata (Saloheimo et al., 1991). In common with these and all other fungal laccases that have been studied, it is to be expected that the $A$. mellea laccases are copper-containing glycoproteins. Direct confirmation of a carbohydrate component of the $\boldsymbol{A}$. mellea laccases has yet to be sought. However, anti-laccase I IgG has been used to immunoprecipitate protein from cell-free translation of $A$. mellea poly(A)-containing RNA in the rabbit reticulocyte lysate system, yielding a single band of $M_{\mathrm{r}}$ 52000 (data not shown). This is consistent with the mature $M_{\mathrm{r}} 59000$ polypeptide containing approximately $15 \%$ carbohydrate as found, for instance, in $\mathrm{Ag}$. bisporus laccase (Wood, 1980). Indeed, variability of glycosylation is a likely contributor to the microheterogeneity shown by laccase I on non-denaturing PAGE analysis (Fig. 6).

The evidence for production of two distinct laccases by $A$. mellea is clear. Laccase I and laccase II were separated 
by ion-exchange chromatography, had different pI values, and antibodies to laccase I did not recognize antigenic determinants on laccase II. Further, antibodies raised against $\mathbf{A g}$. bisporus laccase recognized laccase I, but not laccase II. The properties of laccase II require further investigation. In this study the yield of laccase II was never sufficient to allow characterization. As crude culture filtrates contained essentially similar amounts of laccase I and laccase II activity (Fig. $4 a$ ) it is apparent that the majority of laccase II activity was lost during the purification procedure we have described. From Table 1 it can be seen that the largest single loss of activity occurred at the first DEAE-Sephadex column step. It is conceivable that the majority of laccase II protein was adsorbed to the pigmented polyphenolic material that stuck to this column. There is of course the alternative that most of the laccase II was irreversibly inactivated during this step of the purification.

The correlation between laccase synthesis and rhizomorph development in $\boldsymbol{A}$. mellea is intriguing. It is clear that the initiation of both processes requires the development of aerial mycelium, is favoured by high oxygen tension and is not affected by $\mathrm{CO}_{2}$ tension (Worrell, et al., 1986). Under continuing high oxygen tension, however, laccase activity rapidly declines after reaching a maximum (Fig. 2) and the cultures develop extensive dark pigmentation, presumably as a result of laccase action (not shown; cf. Worrell et al., 1986). If oxygen availability is limited (by sealing culture vessels after inoculation), not only is more laccase recovered (Fig. 2), but the cultures remain substantially unpigmented and rhizomorph synthesis continues for longer (results not shown). The part that laccase might play in rhizomorph development remains unclear. As can be seen from Fig. 1, cultures at pH 7 make marginally more rhizomorphs than cultures at $\mathrm{pH} 5$, but develop only about two-thirds the amount of laccase activity. If the enzymes' response to $\mathrm{pH}$ (Fig. 7) is taken into account, the amount of laccase action in $\mathrm{pH} 7$ cultures is likely to be significantly less than in $\mathrm{pH} 5$ cultures. Thus, if laccase is required for rhizomorph development as others have proposed (Worrell et al., 1986), the amount produced in cultures at $\mathrm{pH} 5$ must be in great excess of this requirement. Furthermore the functions of two quite distinct laccases are at present inexplicable.

We thank Dr J. Rishbeth for generously providing Armillaria strains and for information about their origin. Advice from Professor D. A. Wood on numerous points concerning fungal laccases and the gift of pure laccase from Agaricus bisporus are also most gratefully acknowledged.

\section{References}

ANDER, P. \& ERIKsson, K.-E. (1976). The importance of phenol oxidase activity in lignin degradation by the white rot fungus Sporotrichum pulverulentum. Archives of Microbiology 109, 1-8.

Aramayo, R. \& Timberlake, W. E. (1990). Sequence and molecular structure of the Aspergillus nidulans yA (laccase 1) gene. Nucleic Acids Research 18, 3415.

DE VRies, O. M. H., Kooistra, W. H. C. F. \& Wessels, G. H. (1986). Formation of an extracellular laccase by Schizophyllum commune dikaryon. Journal of General Microbiology 132, 2817-2826.

German, U. A., Muller, G., Hunziker, P. E. \& LerCh, K. (1988). Characterisation of two allelic forms of Neurospora crassa laccase. Amino- and carboxyl-terminal processing of a precursor. Journal of Biological Chemistry 263, 885-896.

Harkin, J. M., LaRsen, M. J. \& Obst, J. R. (1974). Use of syringaldazine for detection of laccase in sporophores of wood rotting fungi. Mycologia 66, 469-476.

Hess, H. H., Lees, M. B. \& DerR, J. E. (1978). A linear Lowry-Folin assay for both water soluble and SDS-solubilized proteins. Analytical Biochemistry 85, 295-300.

Kantelinen, A., HatakKa, A. \& Vilkari, L. (1989). Production of lignin peroxidase and laccase by Phlebia radiata. Applied Microbiology and Biotechnology 31, 234-239.

Kojima, Y., Tsukuda, Y., KaWai, Y., Tsukamoto, A, Sugiura J., SAKAIMO, M. \& KITA, Y. (1990). Cloning, sequence analysis, and expression of lignolytic phenoloxidase genes of the white-rot basidiomycete Coriolus hirsutus. Journal of Biological Chemistry 265, 15224-15230.

KRUgGer, N. J. \& Hammond, J. B. W. (1988). Purification of immunoglobulins using protein A-sepharose. In Methods in Molecular Biology, vol. 3, New Protein Techniques, pp. 363-371. Edited by J. M. Walker. Clifton, NJ: Humana Press.

LAEMMLI, U. K. (1970). Cleavage of structural proteins during the assembly of the head of bacteriophage T4. Nature, London 227, 680685.

Leatham, G. F. \& StahmanN, M. A. (1981). Studies on the laccase of Lentinus edodes: specificity, localization and association with the development of fruiting bodies. Journal of General Microbiology 125, $147-157$

PaCY, J. \& Thurston, C. F. (1987). Distribution of isocitrate lyase in induced and de-adapting cells of the green alga Chlorella fusca. Journal of General Microbiology 133, 3341-3346.

Saloheimo, M., Niku-Paavola, M.-L. \& Knowles, J. K. C. (1991). Isolation and structural analysis of the laccase gene from the lignindegrading fungus Phlebia radiata. Journal of General Microbiology 137, $1537-1544$.

Wargo, P. M. (1990). Spread of Armillaria by rhizomorphs in forest stands. In Fourth International Mycological Congress Abstracts, p. 92. Edited by A. Reisenger \& A. Bresinsky. Regensburg: Botanical Institute.

WoOD, D. A. (1980). Production, purification and properties of extracellular laccase of Agaricus bisporus. Journal of General Microbiology 117, 327-338.

WOOD, D. A. (1985). Production and roles of extracellular enzymes during morphogenesis of basidiomycete fungi. In Development of Higher Fungi, pp. 375-387. Edited by D. Moore, L. A. Casselton \& J. C. Frankland. Cambridge: Cambridge University Press.

Worrell, J. J., Chet, I. \& Hüttermann, A. (1986). Association of rhizomorph formation with laccase activity in Armillaria spp. Journal of General Microbiology 132, 2527-2533. 